\title{
KEMITRAAN ORANGTUA DAN MASYARAKAT DALAM PROGRAM PENDIDIKAN ANAK USIA DINI
}

\author{
${ }^{1}$ Robingatin, Khadijah ${ }^{2}$ \\ ${ }^{1,}$ Institut Agama Islam Negeri (IAIN) Samarinda \\ ${ }^{1}$ robingatin.ms01@gmail.com
}

\begin{abstract}
Families as parents have an important role in the administration of education. Most parents spend their time working rather than interacting with their children, school also do not have effective programs that can improve parent partnerships in PAUD programs. This study aims to deterime the factors that cause low parental partnerships in PAUD programs, the effect of parental partnerships on program management and early childhood development, the design of programs to improve parental partnerships in PAUD programs. This study uses a literature study method with a qualitative approach. The results showed that the low involvement of parent in PAUD programs was due to the socio-economic conditions of parent, parent's educational background, and teacher atau school communication skills.

The influence of the low partnership between parents and schools is due to the gap in the PAUD program, the shortage of human resources, the unsuccessful sustainability of chidren's programs at home, so that children's development is not optimal.
\end{abstract}

Keywords: partnerships, parents, children and PAUD.

\begin{abstract}
Abstrak
Keluarga sebagai orangtua yang memiliki peran penting dalam penyelenggaraan pendidikan. Sebagian besar orangtua menghabiskan waktunya bekerja daripada berinteraksi dengan anak mereka, sekolah juga belum memiliki program efektif yang dapat meningkatkan kemitraan orangtua dalam dalam program PAUD. Penelitian ini bertujuan mengetahui faktor penyebab rendahnya kemitraan orangtua dalam program PAUD, pengaruh kemitraan orangtua terhadap pengelolaan program PAUD, pengaruh kemitraan orangtua terhadap pengelolaan program dan perkembangan anak usia dini, rancangan program peningkatan kemitraan orangtua dalam program PAUD. Penelitan ini menggunakan metode studi pustaka dengan pendekatan kualitatif.

Hasil penelitian menunjukkan bahwa masih rendahnya keterlibatan orangtua dalam program PAUD dikarenakan kondisi sosial ekonomi orangtua, latar belakang pendidikan orangtua, dan kemampuan komunikasi guru atau sekolah. Pengaruh rendahnya kemitraan orangtua dan dengan sekolah disebabkan kesenjangan program PAUD, kekurangan SDM, ketidak berhasilan keberlanjutan program anak di rumah, sehingga perkembangan anak tidak maksimal.
\end{abstract}

Kata Kerja: Kemitraan, orangtua, anak dan PAUD

\section{PENDAHULUAN}

Pendidikan adalah tanggung jawab bersama antara keluarga pemerintah dan masyarakat.Sehingga orangtua tidak menganggap bahwa pendidikan adalah tanggung 
jawab sekolah.Pendidikan juga merupakan suatu usaha manusia untuk membina kepribadiannya agar sesuai dengan norma-norma atau aturan di dalam masyarakat.Setiap orang dewasa yang ada dalam masyarakat dapat menjadi pendidik, sebab pendidik merupakan suatu perbuatan sosial yang mendasar untuk pertumbuhan maupun perkembangan anak menjadi manusia yang mampu berfikir dewasa.

Perubahan paradikma dalam hal hubungan keluarga, masyarakat dan sekolah terjadi seiring perubahan yang ada di dunia yang merupakan akibat dari perubahan zaman.Globalisasi, dengan revolusi informasi dan teknologinya membuat dunia seakan semakin kecil. Batasan waktu hamper tidak ada lagi. Arus informasi mengalir bebas dari suatu belahan bumi ke belahin bumi lainnya

Perubahan dan perkembangan ini merupakan menghilangkan paradikma dan tabulama dalam hal hubungan sekolah, masyarakat dan keluarga.Dalam paradikma lama, keluarga, masyarakat dan sekolah dianggap sebagai institusi yang terpisah oleh karena itu, tabulah kalau masyarakat ikut campur tangan dalam penyelengggaraan pendidikan disekolah.Apalagi kalau sampai masuk ke wilayah kewenangan profesionalisme guru.Sebaliknya, dewasa ini dalam batas-batas tertentu anggapan semacam itu tidak berlaku. Keluarga berhak mengetahui apa saja yang diajarkan kepada anak dengan, metode apa saja anak diajar. Disinilah hubungan antara keluarga dan sekolah mulai terjalin masyarakaat berhak mengetahui apa saja yang terjadi disekolah, bisa memberikan sumbang saran untuk peningkatan mutu pendidikan dari sini lah terjadi hubungan resiprokal saling mengisi dan saling memberi antar sekolah, masyakaat dan sekolah. Hubungan resipokal ini selanjutnya berkembangan menjadi hubungan kemitraan.Kemitraan perlu ditumbuhkan, dikembangan dan diperihara karena adanya masalah dan tantangan yang terjadi dalam upaya untuk memberikan pendidikan yang berkualitas prima.

Model kemitraan Epstein (Fagbeminiyi, 2011) keterlibatan keluarga yang meliputi: mengasuh anak, komunikasi, relawan, belajar dirumah, dan pengambilan keputusan keputusan, serta berkolaborasi dengan masyarakat. Model tersebut menunjukkan bahwa banyak hal yang dapat dilakukan oleh orangtua untuk membangun kerjasama dengan pihak sekolah dalam membangun kolaborasi dalam pendidikan 
anak.Bentuk keterlibatan orangtua berupa kolaborasi dengan masyarakat merupakan wujud integrasi trisentra pendidikan.

Kompleksitas masalah di dunia pendidikan merupakan akibat dari perkembangan zaman serta tuntutan masyarakat menyebabkan tidak ada satu pihak yang bisa memahami dan menyelesaikan masalah yang ada seorang diri.Tidak ada lagi single fighter yang mengatasi semua masalah yang ada.Pergeseran peran utama pemerintah dan swasta sebagai pemasok utama kedalam masyaraat membuat kemitraan semakin nyata urgensinya. Pemerintahan dan swasta menyelenggarakan dan mengaswasi keberlangsungan pendidikan karena adanya keterbatasan sumber daya yang dimiliki dalam mengatasi masalah ini keterlibatan dan partisipasi masyarakat sangat diharapkan. Keterlibatan orangtua dapat dipengaruhi oleh beberapa faktor sosiopolitik, seperti kondisi sosial ekonomi dan pengalaman negarif orangtua ketika bersekolah (Jafarov, 2015). Namun, pena dalam Jafarov (2015) mengidentifikasi bahwa orangtua dengan tingkat pendidikan rendah lebih sering menjadi sukarelawan dalam berbagai jenis kegiatan di sekolah daripada orangtua dengan tingkat pendidikan yang lebih tinggi.

Kemitraan merupakan solusi dalam mengatasi masalah kelangkaan dan distribusi sumber daya dalam semua pihak.Kemitraan ini memungkinkan terjadinya sinergi dalam mencapai tujuan bersama.Ketika kita, pada satu sisi mengharapkan tuntutan zaman, mustahil jika kita masyarakat dan keluarga hanya menumpukan beban dipundak sekolah dan penyelenggaran sekolah.Tuntutan pendidikan yang berkualitas prima dapat dipenuhi jika ada hubungan resiprokal sekolah, keluarga, masyarakat dalam konteks pemberdayaan. Di dalam Alquran disebutkan bahwa "Sesungguhnya Allah tidak akan merubah suatu kaum sebelum mereka mengubah keadaan diri mereka sendiri” (Q.S. Ar Rad (13) 11) yaitu:

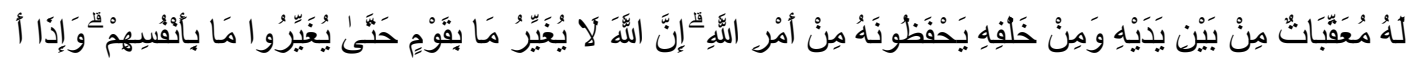

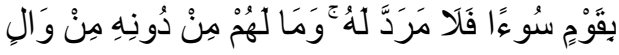

Artinya: Bagi manusia ada malaikat-malaikat yang selalu mengikutinya bergiliran, dimuka dan dibelakangnya, mereka menjaganya atas perintah Allah. Sesungguhnya 
Allah tidak merubah keadaan suatu kaum sehingga mereka merubah keadaan yang ada pada diri mereka sendiri.Dan apabila Allah menghendaki keburukan terhadap suatu kaum, maka taka da yang dapat menolaknya dan sekali-kali tak ada pelindung bagi mereka selain dia.

Partisipasi keluarga dan masyarakat dalam pendidikan tidak bisa dipandang hanya sebatas kewajiban.Partisipasi masyarakat kini adalah hak.Masyarakat seharusnya menuntut untuk menjalankan haknya dengan melibatkan diri dan berpartisipasi dalam penyelenggaraan pendidikan.Hubungan resiprokal sekolah, keluarga dan masyarakat diwujudkan dalam banyak hal. Ada yang bersinggungan langsung dengan proses pendidikan di sekolah dan ada juga yang tidak. Salah satu aplikasi bentuk kemitraan adalah komite sekolah

\section{METODE PENELITIAN}

Metode penelitian ini adalah studi pustaka dengan pendidikan kualitatif.Dalam pendidikan ini, penelusuran pustaka lebih dari pada sekedar melayani fungsi-fungsi. Adapun prosedur dalam melakukan studi pustaka antara lain: (a) menyiapkan alat perlengkapan, (b) menyusun bibliografi kerja, (c) mengatur waktu,dan (d) membaca dan membuat catatan penelitian (Mestika Zed,2008).

\section{HASIL PENELITIAN DAN PEMBAHASAN}

Keberhasilan pendidikan bukan semata karena usaha-usaha yang dilakukan para praktisi di lembaga pendidikan, melainkan banyak factor yang mempengaruhinya.Hubungan yang harmonis antara keluarga dengan lembaga pendidikan menjadi daya dukung utama dalam keberhasilan pendidikan anak.

\section{Hubungan Keluarga dengan Lembaga Pendidikan}

Menurut essa (2003:75) kemitraan keluarga dalam program di lembaga pendidikan dalam program (family involvement) merukan konsep yang multi makna. Bisajadi konsep tersebut bermakna bahwa orang tua dan anggota keluarga lainnya merupakan keompok penerima informasi secara pasif, bisa juga konsep ini merujuk 
pada tingginya keterlibatan orang tua atau anggota keluarga lainnya sebagai sukarelawan di lembaga pendidikan, atau bisa juga lebih kompleks dari itu, yaitu menjadi bagian dari pengambilan kebijakan atau keputusan atas program yang akan dilaksanakan oleh lembaga pendidikan.

Briggs dan potter (1995) seperti dikutip suyanto (2005:225-226) mengemukakan bahwa kerjasama orang tua dengan lembaga pendidikan dikelompokan kedalam dua yaitu: keterlibatan (parent involvement), dan partisipasi (Parent participation). Keterlibatan orang tua merupakan tingkat kerjasama yang minimum, misalnya orang tua datag ke lembaga pendidikan dan membantu lembaga pendidikan jika di undang saja.sebaliknya, partisipasi orang tua merupakan tingkat kerjasama yang lebih luas dan lebih tinggi tingkatannya. Orang tua dan sekolah duduk bersama untuk membicarakan berbagai program dan kegiatan anak.Orang tua dating kesekolah untuk membantu guru melaksanakan tugas-tugas rutin seperti menyiapkan makanan, menyiapkan alat permainan atau media yang dibutuhkan untuk pembelajaran, dan ikut menjadi keamanan.

Peran orang tua di lembaga pendidikan ini, menurut essa (2003:75-77) dapat ditempatkan dengan tiga strategi, yaitu : 1) keluarga sebagai sumber (belajar), 2) anggota keluarga dalam kelas (pembelajaran), dan 3) anggota keluarga sebagai pengambil kebijakan. Keluarga sebagai sumber belajar dimaknai bahwa angota keluarga memiliki minat dan kecakapan yang dapat membantu program di lembaga pendidikan.Banyak lembaga pendidikan dengan program yang dikunjungi orang tua karena program tersebut memiliki relevansi dengan pekerjaan, kemampuan, hobi, dan keahlian yang di intergrasikan ke dalam program.

Di Lembaga pendidikan tersebut.anggota keluarga juga dapat menjadi bagian yang memelihara peralatan pendukung kegiatan pembelajaran di Lembaga pendidikan atau dapat juga memberdayakan anggota keluarga menjadi orang yang mmeperbaiki peralatan yang rusk di lembaga pendidikan.

Anggota keluarga dapat juga menjadi sukarelawan sebagai guru pendamping.Honig (1979) mengemukakan bahwa banyak manfaat apabila melibatkan orang tua dalam kegiatan pembelajaran dikelas.Pada umumnya, keterlibatan di kelas 
lebih banyak terjadi pada tempat penitipan anak (TPA).Kehadiran orang tua dikelas memberikan keuntunggan bagi anak, guru, ataupun orang tua itu sendiri. Anak akan merasa nyaman dan terlindungi manakala melihat orang tuanya bekerja bersama gurunya di kelas. Orangtua dapat mengambil manfaat dari apa yang mereka lakukan bersama guru di sekolah, untuk selanjuntya menjadi perilaku yang dilakukan sehari-hari di rumah, termasuk di dalamnya memahami lebih jauh tentang interaksi anaknya selama kegiatan pembelajaran berlangsung. Sementara itu, bagi guru, keterlibatan orngtua di kelas dapat memperluas berbagai kemungkinan-kemungkinan yang dapat dilakukan oleh orang tua dalam keluarga.

Kemitraan anggota keluarga menjadi pengambil kebijaksanaan dalam program di Lembaga pendidikan memberikan makna bahwa program yang dikembangkan disusun secara bersamaan antara orangtua dengan komponen di Lembaga pendidikan. Duns \& Trivette (1988) seperti dikutip Essa (2003:77) menjelaskan bahwa keterlibatan keluarga dalam pengambilan keputusan dalam lembaga pendidikan dapat mendorong kerjasama antara keluarga dan sekolah, meningkatkan kualitas Lembaga pendidikan, memberdayakan orangtua, dan meningkatkan kerjasama yang saling menguntungkan.

Kemitraan orangtua dalam pendidikan memberikan pengaruh yang berbeda terhadap keberhasilan pendidikan anak-anak. Penelitian yang dilakukan oleh Humpton dan Mumford (1998) seperti yang dikutip Brewer 2007:238) mengemukakan bahwa orangtua dengan keterlibatan yang rendah dalam pendidikan di lembaga pendidikan memiliki perbedan pretasi akademik yang cukup besar dibandingkan dengan orangtua yang berpartisipasi secara penuh. Demikian pula temuan yang dihasilkan oleh Henderson dan Berla (1994) seperti dikutip Brewer (2007:238) yang menyatakan bahwa orangtua yang berpartisipasi dalam sekolah memberikan pengaruh terhadap prestasi anak yang tinggi, memiliki tingkat kehadiran yang bagus di sekolah, memiliki sikap dan tingkah laku positif yang lebih bagus, dan mencapaai pendidikan lebih tinggi.

Kemitraan orangtua dalam lembaga pendidikan menurut Berger (1991:122) dapat dilakukan melalui ; 
1. Melibatkan orangtua sebagai pendidik bagi anaknya

2. Melibatkan orangtua sebagai pengamat proses pembelajaran di kelas

3. Melibatkan orangtua sebagai tenaga sukarela yang bersifat sementara

4. Menjadikan orangtua sebagai sumber tenaga sukarela

5. Menjadikan orangtua sebagai sumber tenaga kerja

6. Melibatkan orangtua sebagai pengambil kebijakan di sekolah

Beberapa alasan utama yang mendasari pentingnya melibatkan orangtua dalam pendidikan di lembaga pendidikan menurut Epstein (1971) seperti dikutip Brewer (2007:238) adalah:

1. Orangtua dan guru lebih banyak memiliki kesamaan dibandingkan perbedaan dalaam mendidik anak. Mereka banyak memiliki tujuan dan kebutuhan yang perlu dibagi satu dengan lainnya

2. Keterlibatan orangtua dalam program tidak hanya berhenti pada pendidikan anak, akan tetapi sebaiknya berlanjut sampai pada jenjang pendidikan berikutnya

3. Program yang disusun lembaga pendidikan melibatkan seluruh keluarga

4. Program yang disusun lembaga pendidikan menjadikan tugas guru lebih mudah

5. Program berkembang seiring dengan waktu

Lebih lanjut Brewer (2007:239) mengemukakan bahwa sekolah yang menerapkan tujuh prinsip dari beberapa prinsip di bawah ini memiliki kesuksesan dalam merencanakan kegiatan bersama orangtua. Beberapa prinsip tersebut adalah:

1. Kunjungan orangtua atau hari observasi

2. Acara khusus keluarga seperti "ice cream social" atau malam keluarga

3. Pameran kurikulum, didalamnya memajang hasil karya anak juga

4. Hari computer orangtua, dimana orangtua dapat belajar teknologi

5. Hari kakek atau nenek

6. Pertemuan informal dengan kepala atau direktur sekolah

7. Informasi pameran musim panas yang menyenangkan

8. Laporan kegiatan orangtua di rumah atau kartu-kartu laporan kegiatan 
9. Kunjungan orangtua ke perpustakaan, kunjungan lapangan, seminar atau workshop yang diikuti

10. Program penghargaan, dimana semua anak mendapatkaj penghargaan untuk berbagai kategori

Dari beberapa konsep yang dikemukakan diatas, maka dalam penelitian ini keterlibatan orangtua dalam program di Lembaga taman kanak-kanak adalah orangtua di kabupaten Bandung yang melibatkan dirinya dalam program di Lembaga taman kanak-kanak dimana anaknya mengikuti pendidikan. Keterlibatan tersebut dikaji dalam tiga dimensi yang disebutkan diatas, yaitu keterlibatan secara pasif (menghadiri undangan), keterlibatan di kelas dalam pembelajaran, dan keterlibatan sebagai pengambil kebijakan dalam pengembangan program di Lembaga taman kanak-kanak.

\section{Kemitraan Orangtua Dalam Program Pendidikan Anak Usia Dini}

Lembaga pendidikan sebenarnya merupakan komponen utama dalam mempersiapkan anak untuk memasuki jenjang pendidikan berikutnya.Akan tetapi, dalam penelitian ini sekolah tidak dimasukkan ke dalam struktur melainkan sekolah sebagai variabel yang memberikan kontribusi terhadap pola asuh mendidik dalam keluarga dengan catatan interaksi diantara dua lembaga ini terjadi secara harmonis. Orangtua yang melakukan hubungan yang baik dengan Lembaga pendidikan taman kanak-kanak dan memanfaatkan informasi tentang pendidikan anak diasumsikan memberikan kontribusi bagi orangtua dalam melakukan interaksi yang mendidik di dalam keluarga. Tucker dan Dyson (1976) seperti dikutip Emilia Dowling dan Elsie Osborne (2002:67) mengemukakan bahwa hubungan yang terjalin dengan baik antara keluarga dan sekolah akan menghindarkan anak dari hal-hal yang memberatkan. Melalui komunikasi yang baik diharapkan tersampaikannya informasi, pesan, dan nilainilai diantara dua lembaga ini.

Adi Wikarta (1988:68) menyebutkan "Keluarga adalah suatu system yang terdiri atas sub system yang saling berrhubungan dan sling pengaruhi satu sama lain". Adapun sub system sosial itu bukan unit-unit fisik, melainkan peran-peran atau fungsi. Sebagai 
sebuah system sosial, keluarga berhubungan dan punya kesaling ketergantungan tertentu dengan keluarga lain dan system sosial lai seperti dengan organisasi, kantor, sekolah, dan lain-lain.

Konsep keterlibatan orangtua bukanlah hal baru di lingkungan pendidikan dan telah memainkan peran yang nyata.Pihak yang terlibat dalam keterlibatan orangtua adalah sekolah, keluarga, dan kemitraan masyarakat.Oleh karena itu, tiga aspek yang saling mempengaruhi tersebut harus disatukan disetiap pendidikan dan pengembangan anak.

Menurut Wolfendale dalam Epstein (1996:81) bahwa "Keterlibatan orangtua secara luas diartikan dalam waktu tertentu diantara para pendidik terkadang menyamakan dengan kemitraan, partisipasi orangtua, kekuasaan orangtua, sekolah, keluarga, dan kemitraan masyarakat.Adapun menurut Moles (1992:87) menyatakan bahwa "Banyak sekali variasi bentuk keterlibatan orangtua dan tingkatan dari keterlibatan tersebut, baik di dalam maupun di luar sekolah". Semuanya mencakup segala kegiatan yang dapat didukung dan didorong oleh sekolah yang memberikan kewenangan bagi para orangtua dalam hal pembelajaran dan perkembangan anak-anak.

Menurut Defense Fund dalam Olsen dan Fuller (2003:136) bahwa "setiap sekolah akan mengunggulkan kemitraan yang akan meningkatkan keterlibatan orangtua dan berpartisipasi dalam pertumbuhan sosial, emosi, dan akademik anak". Hal tersebut tentu saja mendorong sekolah dan kerja sama masyarakat untuk membantu kesuksesan anak-anak dalam pendidikan. Dengan memiliki dasar yang baik dalam bidang keterampilan berkomunikasi, menurut Lindenfield (1997:8), maka anak-anak akan dapat:

1. Mendengarkan orang lain dengan tepat, tenang, dan penuh perhatian

2. Bisa berbincang-bincang dengan orang lain dari segala usia dan segala jenis latar belakang

3. Membaca dan memanfaatkan bahasa tubuh orang lain

4. Bicara di depan umum tanpa rasa takut 
Dengan demikian dapat disimpulkan bahwa keterlibatan orangtua adalah pencapaian tujuan bersama oleh sekolah, keluarga, masyarakat, dan kerja sama tersebut sangat diperlukan anak-anak untuk dapat sukses di dalam pendidikan.

Kemitraan diartikan sebagai hubungan kooperatif antara orang tua atau kelompok orang yang sepakat untuk berbagi bertanggung jawab untuk mencapai tujuan tertentu yang sudah ditetapkan. Dirjen Manajemen Pendidikan Dasar dan Menengah dalam modul pemberdayaan Komite Sekolah menjelaskan bahwa yang dimaksud kemitraan dalam konteks hubungan resiprokal antara sekolah, keluarga, dan masyarakat kemitraan bukan sekedar sekumpulan antara main yang tertulis dan formal atau suatu kontrak kerja melainkan lebih menunjukkan perilaku hubungan yang bersifat intim antara dua pihak atau lebih dimana masing-masing pihak saling membantu untuk mencapai tujuan bersama.

Dari definisi-definisi diatas kita bisa mengatahui bahwa hakikat kemitraan adalah adanya keinginan untuk berbagi bertanggung jawab yang diwujudkan melalui perilaku hubungan dimana semua pihak yang terlibat saling bantu-membantu untuk mencapai tujuan bersama.Model kemitraan sekolah dan orangtua telah layak digunakan sesuai dengan karakteristik daerah. Melalui komunikasi yang efektif dan kekeluargaan dan kolaborasi dengan masyarakat yang lebih luas sehingga partisipasi orangtua dengan sekolah dapat menjadi lebih baik (Taufik Rihatno, Yufiarti, Sri Nuraini:2007).

Brooks (2011:10) mendefinisikan, "orangtua sebagai individu-individu yang mengasuh, melindungi, dan membimbing.Orangtua melakukan investasi dan komitmen abadi pada seluruh periode perkembangan yang panjang dalam kehidupan anak". Orangtua atau keluarga merupakan pusat pendidikan pertama dan terpenting bagi anak.Sedangkan kegiatan parenting tidak lepas dari peran serta orangtua.Parenting adalah sebagai bentuk kemitraan bersama antara orangtua dan anak, untuk memberdayakan potensi anak dengan menyediakan alat-alat yang diperlukan agar masa depannya menjadi lebih baik.Dalam kemitraan yang berlaku adalah prinsip egaliter. Masing-masing pihak yang bermitra memiliki posisi dan tanggung jawab yang sama. Hubungan atasan-bawahan tidak berlaku dalam konteks kemitraan.Masing-masing 
menjalankan fungsi dan perannya sesuai dengan tugas dan batas-batas wewenang yang dimiliki.Selain berkaitan dengan fungsi dan peran masing-masing dalam kemitraan, dalam kemitraan mengandalkan pada kepentingan yang dijadikan andalan.Model kemitraan mengandalkan pada kepentingan pribadi orangtua dan anggota masyarakat yang mau tidak mau membuat mereka berpartisipasi dalam aktifitas yang berkaitan dengan sekolah.

Kemitraan memandang semua pihak yang memiliki kepentingan terhadap sekolah merupakan pihak yang dapat didayagunakan dan mampu membantu sekolah dalam rangka pengingkatan mutu pendidikan.Ada hal-hal yang harus diperhatikan dalam kemitraan. Grant (1979:128) mengingatkan bahwa kemitraan tidak boleh mengabaikan prinsip akuntabilitas dan kemandirian. Dalam hal menumbuhkan kemandirian, secara eksplisit Grant menganjurkan agar setelah terbentuknya kelompok kemitraan masing-masing anggota harus menjaga kentrlan khususnya dalam segi politik.

Adiwikarta (1988:68) menyebutkan "keluarga adalah suatu sistem yang terdiri atas sussistem-subsistem yang saling berhubungan dan saling dipengaruhi satu sama lain”. Adapun subsistem sosial itu bukan unit-unit fisik, melainkan peran-peran atau fungsi. Sebagai sebuah sistem sosial, keluarga berhubungan dan punya saling ketergantungan tertentu dengan keluarga lain dan sistem sosial lain seperti dengan organisasi, kantor, sekolah dan lain-lain. Konsep keterlibatan orangtua bukanlah hal yang baru dilingkungan pendidikan dan telah memainkan peran yang nyata. Pihak yang terlibat dalam keterlibatan orangtua adalah sekolah, keluarga, dan kemitraan masyarakat.Oleh karena itu tiga aspek yang saling mempengaruhi tersebut harus disatukan disetiap pendidikan dan pengembangan anak.

Menurut Wolfendale dalam Epstein (1996:81) bahwa "keterlibatan orangtua secara luas diartikan dalam waktu tertentu diantara para pendidik terkadang menyamakannya dengan kemitraan, partisipasi orangtua, kekuasaan orangtua, sekolah, keluarga, dan kemitraan masyarakat.Adapun menurut Moles (1992:87) menyatakan "banyak sekali variasi bentuk keterlibatan orangtua dan tingkatan dari keterlibatan 
tersebut, baik di dalam maupun diluar sekolah ".Semuanya mencakup segala kegiatan yang dapat didukung dan didorong oleh sekolah dan yang memberi kewenangan bagi para orangtua dalam hal pembelajaran dan perkembangan anak-anak. Menurut Defense Fund dalam Olsen dan Fuller (2003:136) bahwa "setiap sekolah akan mengunggulkan kemitraan yang akan meningkatkan keterlibatan orangtua dan berpartisipasi dalam pertumbuhan sosial, emosi, dan akademik anak". Hal tersebut tentu saja mendorong sekolah dan kerjasama masyarakat untuk membantu kesuksesan anak-anak dalam pendidikan.

Dengan memiliki dasar yang baik dalam bidang keterampilan berkomunikasi, menurut Lindenfield (1997:8) maka anak-anak akan dapat :

1. Mendengarkan oranglain dengan tepat, tenang dan penuh perhatian

2. Bisa berbincang-bincang dengan oarnglain dari segala usia dan segala jenis latarbelakang

3. Membaca dan memanfaatkan bahasa tubuh oranglain

4. Bicara di depan umum tanpa rasa takut

Dengan demikian dapat disimpulkan bahwa keterlibatan orangtua adalah pencapaian tujuan bersama oleh sekolah, keluarga, dan masyarakat.Kerjasam tersebut sangat diperlukan anak-anak untuk dapat sukses didalam pendidikan.

\section{Manfaat dari Kemitraan Orang Tua Dalam Program PAUD}

Menurut pendapat Hendeson dan Berla dalam Olsen dan Fuller (2003:136), tanda-tanda yang paling akurat dari pemahaman siswa disekolah adalah bukan dikarenakan status sosial tetapi tingkat dimana keluarga siswa mampu untuk :

1. Menciptakan lingkungan rumah yang mendorong pembelajaran

2. Menunjukkan harapan yang tingi (tapi masuk akal) untuk pemahaman dan masa depan anak

3. Menjadi pendorong pendidikan anak-anak disekolah dan di masyarakat 
Anderson dan Berla (1994) telah mengkaji dan menganalisis 85 kajian yang telah mendokumentasikan manfaat menyeluruh dari keterlibatan orangtua dalam pendidikan anak. Sebuah keterlibatan orangtua yang direncanakan secara efektif dan diterpakan dengan baik akan memberi manfaat yang sangat banyak bagi orangtua, pendidik, dan sekolah.

Adapun manfaat bagi anak-anak adalah :

1. Anak-anak cenderung lebih paham tanpa memandang latar belakang suku atau ras, status sosial ekonomi maupun tingkat pendidikan orangtua

2. Secara umum anak-anak mendapatkan peringkat, nilai, dan presentasi kehadiran yang lebih baik

3. Anak-anak secara konsisten mengerjakan pekerjaan rumah mereka

4. Anak-anak memiliki harga diri yang lebih baik akan lebih didiplin dan menampakkan pendapat serta motivasi untuk bersekolah

5. Perilaku positif anak-anak tentang sekolah akan selalu berhasil meningkatkan perilaku baik disekolah serta mengurangi pelanggaran disiplin

\section{Ini adalah manfaat bagi orang tua yaitu :}

1) Semua orang tua meningkatkan interaksi dan diskusi dengan anak-anak mereka dan para orang tua menjadi lebih responsive dan sensitive terhadap perkembangan intelektual sosial dan emosi

2) Setiap orang tua lebih percaya diri dalam mengasuh dan terampil dalam sebuah keputusan

3) Semua orang tua pasti memperoleh wawasan tentang perkembangan anak

4) Para orang tua memiliki sebuah pemahaman yang lebih baik tentang semua tugas guru dan kurikulum disekolah

5) Sadar tentang apa yang ingin dipelajari anak-anak, mereka dengan senang hati membantu dan ketika para guru meminta para orang tua terlibat dalam aktivitas pembelajaran didalam rumah

6) Semua persepsi para orang tua terhadap sekolah menjadi lebih baik 


\section{Manfaat pendidik :}

1. Suatu sekolah memiliki sebuah persentasi yang sangat tinggi dalam melibatkan orang tua baik didalam sekola maupun diluar sekolah

2. Semua para guru dan kepala sekolah selalu mendapatkan penghargaan yang lebih baik

3. Keterlibatan orang tua yang konsisten membuat peningkatan komunikasi dan hubungan antara orang tua

4. Para guru dan kepala sekolah memiliki pemahaman yang lebih baik mengenai budaya kelarga dan keluargaan

5. Guru dan kepala sekolah dapat melaporkan sebuah hasil kinerja mereka

Sebuah Manfaat Bagi Sekolah :

1) Semua sekolah yang aktif melibatkan para orang tua dan masyarakat mudah mewujutkan reputasi yang baik didalam masyarakat

2) Semua sekolah lebih pengalaman dalam dukungan masyarakat

3) Program dengan kualitas tinggi dari pada yang tidak melibatkan para orang tua

\section{IMPLEMENTASI KEMITRAAN DALAM PEMBANGUNAN}

Makna kegiatan kemitraan untuk membangun sebuah hubungan orang tua dan anak yaitu ada tiga hal yaitu :

1. Semua berdasarkan kesetaraan antara orang tua dan anak

2. Memperdaya pemikiran, dalam bentuk dialog, diskusi maupun tanya jawwab antara orang tua dan anak yang merangsang sebuah proses pemikiran mendalam bersama anak

3. Semua orang tua mampu memenuhi kebutuhan anak secara kreatif.

\section{KEMITRAANDALAM SEBUAH PEMBANGUNAN DIIMPLEMENTASIKA DENGAN MENGUGGUNAKAN PRINSIP PACTS.}


Adapun maksud dalam pats yaitu :

1) Partisipasi : semua pihak memiliki kesempatan yang sama untuk menyatakan pendapat , memutuskan hal - hal yang menyangkut nasibnya dan bertanggung jawab atas semua keputusan yang telah di sepakati bersama

2) Aksetasi : saling menerima dengan apa adanya dalam kesetaraan . Masing masing memiliki fungsinya sendiri sendiri

3) Komunikasi : masing - masing pihak harus mau dan mampu mengkomunikasikan dirinya serta rencana kerjannya sehingga dapat di koordinasikan dan di sininergikan .

4) Percaya : saling mempercayai dan dapat di percaya untuk membina kerjasama . disini tranparansi menjadi tuntutan dan tidak bisa di tawar.

5) Semua yang terlibat dalam kemitraan harus mampu membagikan diri dan memilikinnya (waktu ; harta ; dan kemampuan ) untuk mempercayai tujuan bersama.

\section{Peran aktif keluarga Yang rendah}

Peran aktif keluarga perlu di dukung oleh komunikasi yang lebih baik antara pihak sekola dan piak orang tua siswa .mayoritas (74persen ) orang tua murid yang terjaring dalam jajak pendapat, mengakui tidak mengetahui pola pembelajaran atau kurikulum yang di terapkan di sekolah. Hal ini menggambarkan minimnya interaktif antara orang tua dan pihak sekolah. 


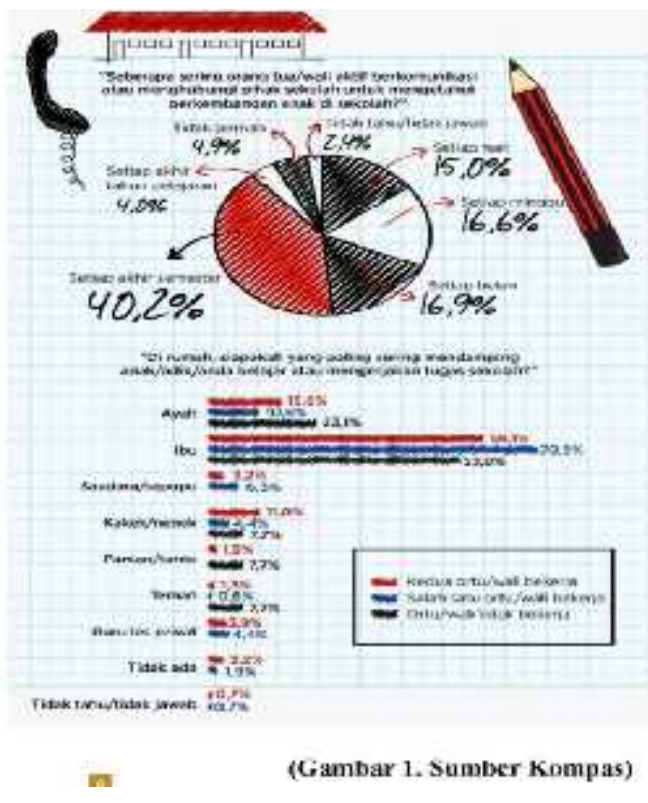

Melibatkan orang tua dalam proses penilian (assesment ) ketika orang tua dan keluarga dilibatkan dalam proses penilian yang kooperatif dari anak mereka, maka mereka akan memberi gambaran akurat dari kekuatan dan kebutuhan mereka . dalam hal ini pihak sekolah bisa merangkul dan bersama - sama membuat rencana program yang akan menemukan kebutuhan mereka . 15 persen orang tua yang terbiasa menanyakan perkembangan sek0olah pada anaknya sehingga kemitraan orang tua pada masih sangat rendah .

Keterlibatan orang tua menurut eka Oktavianingsih (2018) sebagai pihak yang memiliki peran penting dalam penyelanggaraan pendidikan anak usia dini saat masih rendah. Hal tersebut disebabkan oleh dua faktor, yakni faktor orang tua dan adapun faktor sekolah . Faktororang tua dapat berupa kondisi sosial ekonomi dan latar belakang pendidikan orang tua. Faktor sekolah mencakup bahasa dan kemampuan komunikasi guru / sekolah

\section{Cara sekolah dan guru para orang tua}


Sudah sangat jelas dan tidak terbantahkan bahwa keterlibatan orang tua saat sesuai dan memiliki dampak positif yang sangat luas. Meskipun banyak pendidik dan sekolah setuju dan mendukung konsep keterlibatan orang tua serta dampaknya pada anak - anak dari persekolahan sampai sekolah menengah keatas banyak juga yang tidak menyampaikan pengetahuan atau pedoman dalam perencanaan, penerapan, dan hasil yang di capai .

Sedangkan hasil dalam penelitian dalam jurnal milik chang, mengemukakan bahwa bentuk keterlibatan orang tua yaitu seperti relawan kelas pertemuan dewan , konfersi staf orang tua dan kelas pengasuh, pada penelitian tersebut di anggap keterlibat orang tua sebagai penentuan untuk mengeubah perilaku orang tua dan pada gilirannya dapat meningkatkan perkembangan kognitif anak - anak dari keluarga yang status sosialnya ekonominnya rendah.

\section{Penerapan program kemitraan orang tua yang bermakna}

Pada orang tua mengarapkan peningkatkan taraf hidup, latar belakang pendidikan, silahkan keluarga maupun pengalaman dengan sekolah pada masa lalu , serta ingin secara aktif terlibatkan dalam pendidikan anak - anak mereka . Para orang tua lebih senang jika sekolahh menunjukan pada mereka bagaimana terlibat di dalam sekolah.

\section{a. Iklim Sekolah yang Positif}

Bagi sekolah untuk menarik para orangtua dengan sukses, langkah utama yang harus dilakukan adalah menciptakan sebuah suasana sosial budaya yang positif disekolah dan diruang kelas. Iklim sekolah berpengaruh langsung bagi keberhasilan keterlibatan orangtua disekolah dan pendidikan anak-anak (Comer, 1986, Comer dan Haynes, 1991, Dauber dan Epstein 1993)

\section{b. Komunikasi yang Tetap}


Komunikasi adalah komponen paling penting untuk menciptakan dan menangani sebuah bangunan kemitraan dengan keluarga.sebuah komunikasi yang tetap, berkelanjuta dan dua arah dari rumah kesekolah dan dari sekolah ke rumah sangat dibutuhkan.

\section{c. Keberagaman}

Perbedaan dalam struktur keluarga, status ekonomi, latar belakang sosial dan budaya, serta latar belakang pendidikan menjadi perhatian utama dalam membuat perencanaan dan penerapan keterlibatan orang tua.

\section{d. Pelatihan untuk Pendidik dan Orang Tua}

Diadakan pelatihan untuk meningkatkan frekuensi dan ketetapan perkembangan profesional untuk meningkatkan iklim sekolah.Untuk para orang tua pemanduan terus menerus, sesi pelatihan dan pemberian informasi mengenai bagaimana secara aktif terlibat dalam pendidikan anak-anak mereka. Bekerja sebagai satu tim dan kepemimpinan orang tua, serta berkontribusi untuk mewujudkan tujuan sekolah adalah tujuan yang diharapkan pelatihan pendidik dan orang tua.

\section{e. Meningkatkan Program Keterlibatan Orang Tua secara Menyeluruh}

Ketika sekolah mengembangkan program keterlibatan orang tua secara menyeluruh melalui segala bentuk perbedaan keterlibatan.hal tersebut akan menguatkan keberagaman bentuk pelayanan orang tua disekolah. Semua orang tua memiliki anak dengan keterampilan dan kemampuan ketertarikan dan kebutuhan jadwal dan kewajiban usia dan kelas yang berbeda. Oleh karena itu para orang tua dan keluarga akan memberikan tanggapan yang berbeda terhadap permintaan untuk terlibat dalam pendidikan anak-anak. Beberapa orang tua bisa berpartisipasi disekolah selama jam sekolah tapi pada saat ini banyak aktivitas yang mengharuskan para orang tua untuk memilih kegiatan dirumah. Keterlibatan orang tua yang menyeluruh dan fleksibel akan 
mendukung kebutuhan dan ketertarikan para orang tua dan akan memungkinkan para orang tua membangun kekuatan. Tentu saja itu semua dipengaruhi oleh muatan dan tipe keterlibatan orang tua.

Dalam wilayah pendidikan anak usia dini dasar utama adalah orang tua dan guru yang paling berpengaruh, orang tua berpengaruh besar untuk apa yang dilakukan anakanak dirumah, Termasuk juga pendampingan orang tua untuk mencapai tujuan belajar anak. akan lebih banyak waktu yang bersedia dirumah dari pada disekolah untuk belajar dan membangun tingkah laku positif dalam pendidikan.

Pandangan public mengenai kemitraan orang tua berdasarkan sumber data dari L.C. Rose dan A.M. bahwa persentase orang tua dalam menentukan baik atau tidaknya performa siswa disekolah adalah $43 \%$ sedangkan guru $33 \%$ siswa itu sendiri $20 \%$ dan faktor lain hanya 4\%. Hal ini disebabkan karena orang tua lebih militant dalam tuntunan mereka akan pendidikan berkualitas tinggi. keluarga sebagai salah satu dari trisentra pendidikan adalah tempat pendidikan yang pertama dan utama. interaksi ditahun-tahun awal dengan orang tua/pengasuh serta kondisi lingkungan rumah memberikan pengaruh menetap dan jangka panjang pada kemantangan perkembangan dan kesuksesan pendidikan anak.

Sebagai elemen dalam ekosistem yang terdekat pada anak, orang tua dirumah mempunyai banyak keunggulan dan kesempatan untuk menjadi berdaya membentuk perilaku dirinya dan anaknya dalam sistem keluarga. Sistem keluarga yang kuat dan stabil akan memberikan pengaruh positif pada kecakapan hidup anak dan keterhubungan antarelemen sistem lain. Pola pengasuhan orang tua adalah hal yang perlu dipelajari secara terus-menerus agar sensitive dan respontif pada tahap perkembangan anak dan keluarga, proses pendidikan akan berhasil bila keseluruhan ekosistem di sekeliling anak bergerak selaras dan tidak saling menegaskan.

Praktik-praktik pengasuhan sangat beragam dan dipengaruhi oleh budaya dan kondisi lingkungan keluarga.layanan dan program pemerintah tidak melakukan penyeragaman, namun menyambut keberagaman budaya untuk memperkaya rujukan 
dan berkonstribusi pada perbaikan. pemerintah perlu melakukan lebih banyak intervensi khusus bagi masyarakat mendapat akses terhadap rujukan praktik-praktik baik pengasuhan. Salah satu tujuannya adalah sejak awal mencegah dan mempersempit kesenjangan kesempatan dan pencapaian antar daerah, antar status sosial ekonomi dan antar jenis kelamin.

\section{SIMPULAN DAN SARAN}

Berdasarkan penelitian yang telah dilakukan, maka penelitian ini meyimpulkan bahwa Keterlibatan keluarga sebagai pihak yang memiliki peran penting dalam penyelenggaraan pendidikan anak usia dini saat ini masih rendah, hal tersebut disebabkan oleh faktor orang tua kondisi sosial ekonomi dan latar belakang pendidikan orang tua. faktor sekolah kemampuan komunikasi guru/sekolah pengaruh rendahnya keterlibatan orang tua terhadap pengelolaan program PAUD adalah ketidaksesuaian program PAUD yang dapat memenuhi kebutuhan anak dan orang tua, kekurangan pembiayaan, kekurangan SDM (selain guru), ketidakberhasilan keberlanjutan program anak dirumah. Pengaruh keterlibatan orang tua yang rendah terhadap perkembangan anak adalah perkembangan anak yang diharapkan tidak akan berkembang secara maksimal. Maka diperlukan adanya program seperti: (a) menciptakan komunikasi yang inten dengan keluarga , (b) mengadakan rapat/pertemuan rutin antara guru dan orang tua, (c) home visiting (d) keterlibatan orang tua dalam proses penilaian, serta (e) merancang kegiatan -kegiatan sekolah bersama-sama

Dalam pola kemitraan yang sifatnya sukarela tetapi sekaligus hak, prinsip yang diterapkan adalah prinsp egaliter. kesetaraan dalam kemitraan diimplikasikan dalm prinsip PACTS dimana setiap orang memiliki partisipasi sesuai dengan kemampuan satu sama lain bisa saling menerima yang bisa saling mengkomunikasi diri dan rencananya, direkatkanoleh rasa saling percaya juga kemauan untuk saling berbagi kemampuan waktu dan harta untuk mencapai tujuan bersama.

Melibatkan kerja sama dengan orang tua dan masyarakat dalam pendidikan merupakan kebutuhan sekolah terjadi simbiosis mutualisme ketika keterlibatan orang 
tua dapat difasilitasi dengan baik. Banyak jalan yang bisa ditempuh sekolah untuk menarik para orang tua agar terlibat dalam segala aktivitas sekolah. tapi tentu saja semua bentuk dorongan sekolah untuk melibatkan para orang tua dalam pendidikan harus memperhatikan latar belakang sosial, ekonomi, dan pendidikan tiap keluarga. Karena semua keluarga memiliki kebutuhan dan kepentingan yang berbeda untuk anakanak mereka.

\section{DAFTAR PUSTAKA}

Brink,M.B (2002).Involving Parents in Early Childhood Assessment Perspectives From an Early intervention Instructor. Early Childhood Education journal, 29(4).

Brooks,J.2011.The Process of Parenting. Terjemah Fajat, R. 2011, Yogyakarta: Pustaka Belajar. (Brooks,2011:13)

Chang, M.Park,B.\&Kim,S.2009. Parenting Classes Parenting Behavior, and Child Cognitive Development in Early head Start:A Longitudcinal Model, The School Community Journal.19 (1):155-174.

Departemen Pendidikan Nasional Dirtjen Mandikdasdmen 2006,Pemberdayaan Komite Sekolah

Djamarah, Syaiful Bahri,2004, Po;A Komunikasi Orang Tua Dan Anak Dalam Keluarga , Jakarta:Pt Rineka Cipta

Dwiningrum, Siti Irene Astute , 2011. Desentralisasi Dan Partisipasi Masyarakat Dalam Pendidikan, Yogyakarta: Pustaka Pelajar.

Dunst, C. J., Brunder,M.B., \&Espe-Sherwindt, M . (2014). Family Capacity-Building In Early Childhood Intervention :Do Context And Setiing Matter? School Community Journal, 24 (1), 37-49. 
Eka Oktavianingsih. Pengembanganprogram Pelibatan Orang Tua Dalam Penyelenggaraan Pendidikan Anak Usia. Journal Of Early Childhood Care \&Education Je C C E Issn :2615.2018,Vol.1 No.2, 1-15.

Epstein J. L, 1996 Improving School-Family -Community Partnership In The Middle Grandes. Middler School Journal,28 (2),43-48

Fagbeminiyi, F.F (2011). The Role Of Parents In Early Childhood Education :A Case Study Of Ikeja, Lagos State, Nigeria. Global Journal Of Human Social Science, 11(2).

Gael Lindenfield.1997.Mendidik Anak Agarpercaya Diri:Pedoman Bagi Orang Tua.Arcan:Jakarta

Glen Olsen And Mary Lou Fuller. 2003. Home School Relation. Boston Usa ; Pearson Education Inc

Grant, Carl A. 1979. Community Participation In Education. Boston ; Allyn And Bacon, Inc.

Jafarof, J. (2015). Factor Affecting Parental Involvement In Education ; The Analysis Of Literature. Khazar Journal Of Humanities And Social Sciences 18 (4).

Mariana, Rita Dkk. 2010 Pengelolaan Lingkungan Belajar. Jakarta : Prenada Media.

Mauriece Balson. 1999. Menjadi Orang Tua Yang Sukses.Jakarta : Pt. Gramedia Widia Sarana Indonesia.

Moch.Shochib.2010. Pola Asuh Orang Tua.Jakarta : Pt. Asdi Mahasatya

Mohamad Dani Wahyudi. (2016).Implementasi Manajemen Partisipasi Orangtua Dalam Pendidikan Anak Usia Dini (Paud) Di Lembaga Paud Mawaddah Banjarmasin Jurnal Paradigma, Volume 11,Nomor 2, Juli 2016. 
Okeke, C.I.2014.”Effective Home-School Partnership : Some Strategies To Help Strengthen Parental Involvement“. South African Journal Of Education .34 (3) Hal. 1-9.

Patmonodewa,S.2008. Pendidikan Anak Prasekolah. Jakarta: Rineka Cipta.

Prabhawani, S.W.2016.Pelibatan Orang Tua Dalam Program Sekolah Di Tk Khlifah Wirobrjan Yogyakarta Jurnal Pendidikan Guru Pendidikan Anak Usia Dini Edisi 2,5 (2):205-218.

Rich.Dorothy.2008. Menciptakan Hubungan Sekolah-Rumah Yang Positif. Jakarta:Pt Macanan Jaya Cemerlang.

Saesti Winahyuprabhawani. (2016). Pelibatan Orang Tua Dalam Program Sekolah Di Tk Khalifah Wirobrajan Yogyakarta. Jurnal Pendidikan Guru Anak Usia Dini, Edisi 2.

Taufik Rihatnol, Yufiarti,Sri Nuraini. Pengembangan Model Kemitraan Sekolah Dan Orang Tua Pada Pendidikan Anak Usia Dini. Jurnal Pendidikan Usia Dini Volume. 2017,Edisi 1.

Wiyani, N.A. 2014. Mengelola\&Mengembangkan Kecerdasan Sosial \&Emosi Anak Usia Dini. Yogyakarta:Ar-Ruzza Media. 